This item was submitted to Loughborough's Research Repository by the author.

Items in Figshare are protected by copyright, with all rights reserved, unless otherwise indicated.

\title{
Synthetic Beuys: on nano-materials and the aesthetics of imperceptibility
}

PLEASE CITE THE PUBLISHED VERSION

https://doi.org/10.7238/a.v0i15.2549

PUBLISHER

Fundacio per la Universitat Oberta de Catalunya

VERSION

VoR (Version of Record)

PUBLISHER STATEMENT

This is an Open Access Article. It is published by FUOC under the Creative Commons Attribution 3.0 Spain Licence (CC BY 3.0 ES). Full details of this licence are available at:

https://creativecommons.org/licenses/by/3.0/es/deed.en

\section{LICENCE}

CC BY 3.0

\section{REPOSITORY RECORD}

Heinzel, Tincuta. 2015. "Synthetic Beuys: On Nano-materials and the Aesthetics of Imperceptibility". Loughborough University. 
http://artnodes.uoc.edu

\title{
ARTICLE
}

\section{NODE: «ART MATTERS»}

\section{Synthetic Beuys: on Nano-Materials and the Aesthetics of Imperceptibility}

\author{
Tincuta Heinzel \\ Nottingham Trent University \\ 2580 Association
}

Submission date: April 2015

Accepted date: April 2015

Published in: June 2015

\begin{abstract}
This paper brings into attention the paradoxical nature of nano-objects and analyses the relationship between an imperceptible matter (too small to be perceived by the senses) and its forms of sensible manifestation.

The development of nano-sciences and nano-technologies would have not been possible without the invention of a number of visualisation instruments (like the STM - Scanning Tunnelling Microscope and the AFM - Atomic Force Microscope). From this perspective, we can speak of nano-particles as "image-objects" (Sacha Loeve), as a mediated matter. If there are a series of research projects related to the nature of epistemological inquiry in the field of nano-sciences and nano-technologies, there are still a few concerns related to the changes that occur in the field of aesthetics when it comes to the apprehension of nano-technologically treated materials.

By taking into account the latest developments in the field of nano-technologies applied to textiles, the present paper examines the way the status and the significance of materials change when they are nano-technologically treated. In order to do so, we propose a fictional scenario related to some of Joseph Beuys' works in which we replace the "traditional" fabrics used by the artist with new ones, nano-technologically produced or treated. By using Joseph Beuys's artistic approach as a methodological tool of critical enquiry, we are looking to the ways the perceptive, epistemological and semiotic categories are to be re-evaluated when related to nano-technological approaches. The analysis will help to formulate some of the issues artists, designers and researchers should consider when dealing with what we call the "aesthetics of imperceptibility" of nano-materials and nano-technologies.
\end{abstract}

\section{Keywords}

nano-technologies, nano-textiles, Joseph Beuys, aesthetics of imperceptibility, aesthetics of nano-technologies 


\section{artnodes}

http://artnodes.uoc.edu

Synthetic Beuys: on Nano-Materials and the Aesthetics of Imperceptibility

\section{Beuys sintético: sobre los nanomateriales y la estética de la imperceptibilidad}

\section{Resumen}

Este trabajo centra la atención sobre la paradójica naturaleza de los nanoobjetos y analiza la relación entre una materia imperceptible (demasiado pequeña para ser percibida por los sentidos) y sus formas de manifestación ostensibles.

El desarrollo de las nanociencias y la nanotecnología no habría sido posible si no se hubiera inventado una serie de instrumentos de visualización (como el microscopio de efecto túnel y el microscopio de fuerza atómica -STM y AFM según sus respectivas siglas en inglés-). Desde este punto de vista, podemos hablar de nanopartículas como «imágenes-objetos» (Sacha Loeve), como materia mediadora. Si bien existen algunos estudios sobre la naturaleza de la investigación epistemológica en el campo de las nanociencias y las nanotecnologías, es escaso aún el interés por los cambios que se producen en el campo de la estética en relación con la comprensión de los materiales tratados mediante nanotecnología.

Teniendo en cuenta los últimos desarrollos en el terreno de la nanotecnología aplicada a los materiales, este trabajo analiza cómo cambian el estatus y la significación de los materiales cuando se tratan nanotecnológicamente. Para ello proponemos un escenario ficticio relacionado con algunas de las obras de Joseph Beuys en las que sustituimos los tejidos «tradicionales» utilizados por el artista por otros nuevos, producidos o tratados con nanotecnología. Utilizando el planteamiento artístico de Joseph Beuys como herramienta metodológica de investigación crítica, estudiamos cómo tienen que ser reevaluadas las categorías perceptivas, epistemológicas y semióticas cuando están relacionadas con planteamientos nanotecnológicos. El análisis nos ayudará a formular algunas de las cuestiones que artistas, diseñadores e investigadores deberían tener en cuenta al tratar con lo que nosotros llamamos «estética de la imperceptibilidad» de los nanomateriales y las nanotecnologías.

\section{Palabras clave}

nanotecnologías, nanotejidos, Joseph Beuys, estética de la imperceptibilidad, estética de las nanotecnologías

\section{Introduction}

Today, we live in a world where the research on nano-scale materials promises to revolutionise the near future. Carbon nano-fibres and carbon nano-tubes will be soon part of the unseen infrastructure that will shape our world, our knowledge and even our bodies. Not only that, we are witnessing a competition of mastering the new possibilities offered by nano-technologies, but a number of research projects are looking to explain the nature of nano-particles and the impact they have into society. ${ }^{1}$ Still, given the scale of nano-particles (they are too small to be perceived by the common senses), we find ourselves facing the dilemma of how to commonly deal with these new materials and what kind of strategies can be developed in order to approach these new materials. Last but not least, we can also ask ourselves what is going to be the role of designers in shaping the new world when dealing with what I call the "aesthetics of imperceptibility" of nano-materials.

The present paper takes the nano-technologies applied to textiles as a study case. The choice is justified both by the fact that textiles are one of the major application field for nano-technologies, but also because a number of production technologies used in the fabrication of nano-objects are borrowed from the textile industry (see the electro-spinning and nano-scale printing methods).

In order to bring forward the changes that occur with the nano-technologically treated materials, we will consider the works of Joseph Beuys. A key figure of contemporary art, Joseph Beuys is often associated with the use of felt and textiles in his works,

1. See for example GOTO - "Genesis and ontology of technoscientific objects", a project conducted by Bernadette Bensaude-Vincent at Paris1 University (France) in collaboration with Alfred Nordmann at Technical University Darmstadt (Germany) <http://www.goto-objects.eu>. 
materials which, along fat, honey, stones and metal are part of his understanding of what art is: a material encoded message aiming to social and political emancipation. The materiality of his works is therefore manifold, engaging both the physical processes and the semiotics ones. It is precisely this complexity that is of interest for us and will help us to point out to some of the aspects we should consider when dealing with nano-materials. Our approach is to propose a fictional scenario related to three of Joseph Beuys' works in which we will replace the "traditional" fabrics used by the artist with new ones, nano-technologically produced or treated.

\section{Aesthetic aspects related to nano-sciences and nano-technology proccesses}

Intensely debated terms for over a decade now, nano-sciences and nano-technologies ${ }^{2}$ define a research field composed of a heterogeneous set of knowledge, from theories, models and knowhow to disciplines like physics, chemistry and biology (Klein \& $\mathrm{Co}$., 2008). Considered by many as merely a political and marketing umbrella for different forms of research (Loeve, 2008), what brings together nano-sciences and nano-technologies is the scale of the researched objects defined in nanometres. ${ }^{3}$

The imperceptibility of nano-sciences' objects requires not only for a significant arsenal of scientific and technical practices and instruments, but also contributes to the configuration of a series of "big discourses" which redesign the collective imaginary. Between these discourses we can find the "naturalisation of the artifice" which is looking to put into historical perspective the capacity of the biological world to auto-reassemble - and its counterpart "the artificialisation of nature" (Bensaude-Vincent, 2009). And often, as some researchers have pointed out, science fiction is used as a strategy of communication (Loeve, 2008), translating in this way an effect of "cryptotechnicity", in the sense defined by Gilbert Simondon (Simondon, 1960) as a modality to cover the way of functioning of the technical objects, as pseudo-technicity.

The use of science fiction as strategy of communication is also the result of a discursive corpus accompanying the nano-sciences, which relates not only to the present state of the nano-objects, but also to their future application, their virtual, possible future forms. As Eric Drexler puts it, it is not only about "what can be studied today", but also about "what can be built tomorrow" (Dexler, 1992, p. 75), trying to point in this way to the difference between a scientific perspective and an engineering one, between engaging in learning new facts about nature (and avoiding speculation on the future) and engaging in building new devices (where the future possibilities are often essential). ${ }^{4}$

It is precisely the conception and the control of the material processes that explain the interest related to the visualisation and sonification phenomena. It is certain that the development of nanotechnologies has been conditioned by the invention of a number of visualisation instruments (like the STM - Scanning Tunnelling Microscope and the AFM -Atomic Force Microscope) and manipulation instruments (like optical tweezers). It is the fact that nanotechnologies allow us to see the atoms that leads Sacha Loeve to declare that with the arrival of nano-objects we deal with "image-objects" (Loeve, 2009, p.15), meaning that the images are not an exterior translation of nano-particles, but part of the nano-particles' own modes of existence. In other words, the nano-particles' ways of representation are part of the nano-particles' definition. And, to borrow a term used by Enzo Manzini, the "super-sight" (Manzini, 1989) can be considered a new sensory channel, which goes incomparably farther away and more profoundly than common experience. Even though the present state of the technological imagery does not allow for a perfect caption of the properties of particles, the molecular imagery plays an important role in the research projects related to nano-technologies. And it is precisely this role of molecular imagery that leds David Goodsell to speak about a "recreational nano-design" (Goodsell, 2009), a term describing the way in which the imagery methods and results participate in the study and the elaboration of the nano-objects.

Still, as regards the visualisation and the sonification processes, we have to differentiate between the use of imaging methods in order to study and produce nano-technologic materials and the attempts to make the processes that take place on a nano-scopic scale visible or audible to our senses. From this latest point of view, the visualisation and the sonification of nano-scopic processes into macroscopic structures goes further than the "inter-instrumentality", defined by Catherine Allamel-Raffin (Allamel-Raffin, 2010) as the way to obtain convergent information about the studied samples. It is not only to test the information, but also to make it operational.

2. The term nano-technology was first coined in 1974 by Norio Taniguchi at the University of Tokyo in Japan, being later picked up by Eric Dexler in his book Engines of Creation: The Coming Era of Nanotechnology, Anchor Books: New York, 1986.

3. According to the definition given by United States' National Nantechnology Initiative, nano-technology is defined as the "understanding and control of matter at dimensions between approximately 1 and 100 nanometers, known as the nanoscale, where unique phenomena enable novel applications. Encompassing nanoscale science, engineering, and technology, nanotechnology involves imaging, measuring, modelling, and manipulating matter at this length scale" (National Nanotechnology Initiative (NNI). <http://www.nano.gov>). If we agree on this definition, then once with nano-technologies we have to deal not only with the development of ways to conceptualise and to control the nano-scale processes, but also with the development of an intervention cycle at a nanostructural level.

4. See also the difference between science and techno-science, where techno-science should be understood as a type of activity where experimental sciences, technologies and industry hybridise each other, while the distinction between basic and applied sciences is not maintenable anymore. 
This very fact is noticeable when trying to answer pragmatic issues like, for example, signalising the presence of noxious substances in specific work environments. ${ }^{5}$ These kinds of research projects dealing with the translation of nano-scale processes into macroscale perceptible environments have to take into consideration not only technical concerns, but also aesthetic and semiotic ones. What is at stake in this kind of research is the translation of nano-scale processes into adequate perceptible visual and sound signalisation systems in order to make them operational in the "human scale organisation" (Bennett, 2008).

The present paper addresses precisely the aesthetic issues related to nano-particles operability in everyday contexts and questions the changes that occur in the nature of aesthetics inquiry when approaching the nano-technologised materials. Given the latest developments, we can ask ourselves which strategies should we consider for the translation of the nano-scale world into the macro-scale world? And what aspects should then be considered from a critical point of view:

- those related to the technological approaches and their difficulties;

- those trying to break down the "criptotechnicity" which results from the gap that exists between the technical reality and the communicational strategies that accompany it;

- those related to the social impact of the application of nanotechnologies;

- or those related to the critical aspects of the art world and, respectively, of the science world?

There is a common understanding that with todays' nanotechnologies there is a certain abstraction, a certain invisibility and an instability of the matter. But what interests us in this paper is how the aesthetic and perceptive aspects transform themselves under the new ontological conditions of the matter.

\section{Nano-textiles and the materiality of the nano}

Choosing textiles in order to take a closer look into the world of nano, it is not without reason. Textiles are one of the most important areas of application of nano-technologies. And from this point of view, it is probably relevant enough to mention that the European Commission ${ }^{6}$ cites textiles among technologies of information and electronics, energy and environment, as well as healthcare, as one of principal fields of application of nanotechnologies. If the cited fields are areas of well-defined applications, textiles are not in themselves such a domain, being rather an umbrella for different ranges of uses: from clothing to interior design and from building engineering to agriculture.

of course, one should not forget that the fibrous state counts as one of the four possible configurations of synthetic composites (Manzini, 1989) apart from single foils, the composites with an organic aspect (sponges) or the films and plates obtained by stratification of several materials. The fibrous formalisation of synthetic materials is preferred for properties such as length, finesses, flexibility, elasticity, extensibility, rigidity and softness.

At the same time, some of the nano fabrication methods were already in use in the textile industry, if we think of nano-printing (quantum dot) and electro-spinning. The production of nano-materials is possible by both top-down and bottom-up approaches: either by the break of the bulk materials into smaller sizes (through mechanical and chemical manipulation means) or by chemical synthesis or selfassembly of atoms and molecules in order to produce nano-structured materials (molecules and particles as raw materials). Applied to textiles, we will have two different approaches: the modification and the enhancement of natural fibres (cotton, wool, silk) with nanoparticles (electrostatic self-assembly, atomic layer deposition techniques and so on); and the nano-manufacturing of polymeric fibres using directed assembly techniques to create fibres with specific properties (see the website of the Nanotextile department of Cornell University).

The aim of all these fabrication process is either to improve the functionality of fibres, either to build up fibres with high-performance qualities. In both cases, the intentions are to control the electro conductive/antistatic properties of the fibres, to increase their durability, to impregnate them with anti-bacterial properties (especially for applications in medicine), to develop self-cleaning/dirt and water repellent fibres or to make them resistant to the UV radiations or fireproof. Some of the most common interventions are those related to the use of carbon nanotubes (CNT), silver nano-particles (Si02 as matrix), titan oxide nano-particles (TiO2), zinc oxide nano-particles (Zn0), copper nano-coatings (Cu) or montmorillonite (nano-clay) used for drug-delivering fibres, for example. But in order to better understand the materiality of nano-textiles, let's look at some examples.

\subsection{Improved cotton fibres}

Well-known for their absorbing and breathing properties, as well as for their softness, cotton fibres are less qualified for certain applications due to their weak resistance and durability, their flammability or their easy exposure to dirt. Combined with nano-technologically treated synthetic fibres, cotton threads can gain resistance or can prove to be more resistant to dirt.

5. See the projects of Textiles Nano-technology Laboratory, Cornell University: <http://nanotextiles.human.cornell.edu>. [Accessed : 14th of November 2014]

6. See European Commission website dedicated to the Research and Innovation: <http://ec.europa.eu/research/industrial_technologies/nanotechnology-fields_en.html> [Accessed: 14th of November 2014]. 
3.2. Titanium oxide (Ti02) and zinc oxide (ZnO) treated textiles It was also proved that combining titanium oxide nano-particles (Ti02) or even combining zinc oxide nano-particles with organic and inorganic substances favours a better scratch of textiles surfaces, a better resistance to ultra-violet (UV) radiation, as well as a better protection against the electromagnetic field or even again the exposure to infrared (Sawhney, 2008). From this point of view, we can speak of "reinforced" materials that combine the basic properties of natural textile materials with those of synthetic materials. Even if the gained properties are not completely similar to those of the natural materials, the combination of properties will always be interesting for some textile applications. Some of these textiles are used as filters.

\subsection{Nano-silver coating for anti-bacterial and fungicidal fibres} Treating the textile fibres with silver nano-particles, well known for their anti-bacterial properties, is an important research field especially concerning the medical applications. But not only this, if we think of the range of products like different napkins and socket pieces using silver which recently flooded the market.

\subsection{Polyurethane micro-porous membranes}

Micro-porous polyurethane membranes are used when there is need for environment reactive substrates. An example in this sense is Porelle Kyroderm medical membrane produced by KL Technologies Ltd in Great Britain, which is waterproof, breathable, metal detectable, skin friendly, soft and, last, but not least, acts as a viral barrier.

\subsection{Kevlar (by DuPont)}

Developed in 1965 by Stephanie Kwolek at DuPont, Kevlar is a paraamid synthetic fibre. It is a high-performance organic material due to its outstanding thermal and mechanical resistance. Lightweight and extraordinarily strong, Kevlar fibres can have five times the strength of steel on an equal-weight basis.

Combined with zinc oxide nanowires, Kevlar fibres have been used by Adam Whiton and Yolita Nugent to create the "no contact jacket", a conducted energy clothing (CEC) which acts as a last line of defence during an assault. When activated, an aggressor touching the exterior surface of the CEC receives a high-intensity non-lethal charge that causes them to immediately withdraw contact.

\subsection{Drug-delivery textiles}

Drug-delivery textiles are an entire area of research, considered to be less invasive than swallowing drugs. One example of these can be the iLoad system developed by Schoeller Textiles. Its principles consist in using a base fabric layer onto which a special donor layer is applied and anchored. The donor layer, which coats every fibre of the fabric, is combined with a specific emulsion with the required active substances. Between the two layers there are electrical exchanges so that the negatively charged donor layer attracts the positively charged customised active agent emulsion and stores it like a sponge.
Of course, there is a certain number of aspects that should be questioned when dealing with research on nanotechnologies. One of the major issues is related to the environmental impact of such materials. Recent studies have proved that the elimination of silver nano-particles into the sewers has consequences on fish population development. No less important are the health-security measures to take into consideration for those working in research and production of nano-materials. For the time being, there are very few research projects on the long-term effects of nano-materials. As there are no advanced regulations related to the description of what nanomaterials contain, which led journalist Oliver Stuart to ask for new regulations on the market (Stuart, 2011).

\section{Synthetic Beuys}

Trying to answer the questions related to the aesthetic of nanomaterials, our assertion is that, beyond the difference of scale, there are still aesthetics concepts that continue to be at work in art and design productions making use of nano-materials. Still, there are some phenomenological conditions that are not the same, conditions we should consider. These conditions, as the duration of material processes and their reversibility, have changed dramatically.

In order to test our assertion, we propose a fictional scenario related to some of the works of Joseph Beuys in which we will replace the "traditional" fabrics he used with new nano-textiles. By making reference to Beuys's concept of art, we will try to see in which way his conception of art is transformed by the new material configurations. In which way the sense and the signification of the selected works change if we are about to replace the "traditional" textile materials with the new enriched ones? In which way the perceptive, epistemological and semiological categories are to be re-evaluated when it is to consider a nano-structural approach?

Joseph Beuys centred his artistic investigations on what he called "the idea of plasticity" (Harlan, 1986). He defined art "as a field of energy, and the objects of art as symbols of that energy" (Causey, 1998, p. 73) and referred to his performances and actions as "social sculpture", releasing energy for social change. His fetish materials were fat, felt and honey, which he had chosen in relation to his mythified biography, but also because of their association with the first industrial age.

In his words:

My objects are to be seen as stimulants for the transformation of the idea of sculpture, or of art in general. They could provoke thoughts about what can be and how the concept of sculpture can be extended to the invisible materials used by everyone:

Thinking Forms : how we mould our thoughts or 


\section{artnodes}

http://artnodes.uoc.edu

Spoken Forms - how we shape our thoughts

into words or

SOCIAL STRUCTURE - how we mould and shape

the world in which we live:

Sculpture as an

evolutionary process;

everyone an artist.

That is why the nature of my sculpture is not fixed and finished. Processes continue in most of them: chemical reactions, fermentations, colour changes, decay, drying up. Everything is in a state of change. (Beuys, 1973)

As this fragment shows, Joseph Beuys' works are to be seen not merely as objects, but as substances, transforming themselves and gaining shapes and meanings through interaction with the environment and through our direct contact with them. His works recall pre-modern and mythological times, testifying of a declining sense of connexion between material and spiritual unity.

But let's us now imagine how his works will change under the influence of new nano-materials.

\subsection{Scheefall (Snowfall) (1965)}

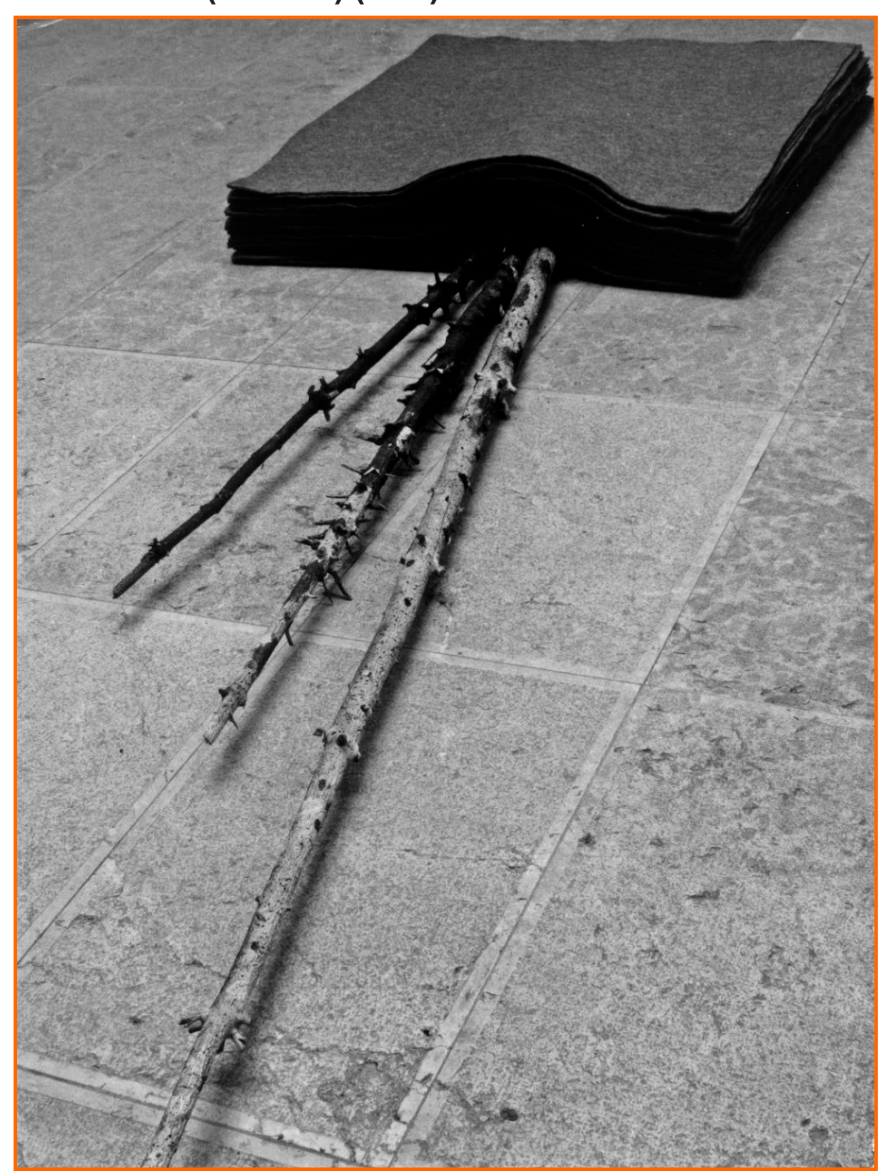

Fig. 1. Joseph Beuys - Snowfall (1965) - 16 felt mats on 3 peeled pine trunks, 120 × $375 \mathrm{~cm}$.
Synthetic Beuys: on Nano-Materials and the Aesthetics of Imperceptibility

Commenting on his felt sculptures, Beuys refers to felt as a heat reservoir or power station. Exhibited directly on the floor, Snowfall is realised of 16 superposed layers of felt covering three peeled pine trunks. The work has to be understood as what Beuys calls a "static action", describing the becoming of the snow. At the same time, there is an invisible relation between the viewer and the absent artist who deploys it: Snowfall relates both to the action of installing the work as well as to the process of felting, though of material transformation. There is also a sound dimension of the work when one thinks of the sound insulating qualities of the felt. Precisely because of all these layers of interpretation, we can refer to this sculpture as a not fixed and unfinished work.

But how will we refer to this work if we will know that the felt was initially treated with titanium-oxide particles in order to make it water repellent or if it was nano-technologically treated to deliver drugs? There is certainly a material transformation and a certain reaction to the environment or, in other words, there is a work of the material, but still, its conceptualisation is totally different from that of natural materials.

\subsection{I like America and America likes me! (1974)}

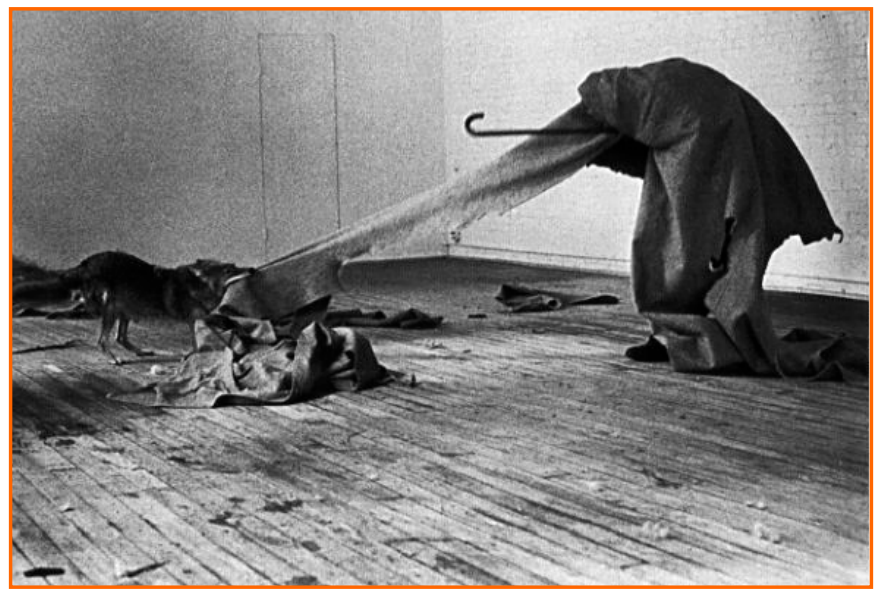

Fig. 2. Joseph Beuys - I like America and America likes me! (1974). Performance with a coyote and felt.

I like America and America likes me! is one of Joseph Beuys's betterknown "actions" performed in 1974 on his first encounter with the American art scene. The artist spent three days in a gallery with a coyote, gathering a felt blanket around him to suggest the figure of a shaman or of a shepherd. The coyote changed behaviour during the three days, from cautiousness to aggression, trying in some occasions to attack the artist. The artist would protect himself from the coyote with the help of the felted cover. The performance makes references to Native American culture and the use of the felt is related to the idea of trauma and healing.

How would this action have been interpreted if instead of felt he would have used Kevlar treated with zinc oxide nanowires? Every time the coyote had touched the Kevlar blanket, it would have received a high-intensity non-lethal charge that would have caused it to immediately withdraw contact. The behaviour of the coyote would 
probably have been totally different and the registers of the work would have been completely disturbed.

\subsection{Felt suit (1985)}

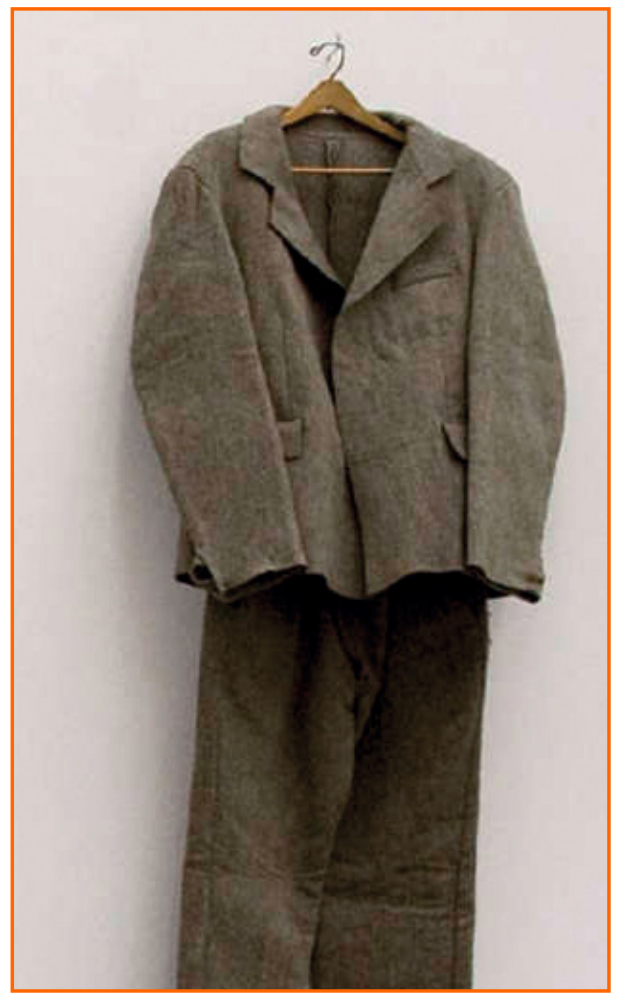

Fig. 3. Joseph Beuys - Felt suit (1970).

Felt suit is part of a series of actions that Beuys defined as a combat against the elitism of the art world. The use of humble materials was part of his strategy. Joseph Beuys wore the suit during the performance Action the Dead Mouse / Isolation Unit from 1970 and referred to the suit as an extension of the sculptures he made with felt, where the insulating properties of the material were integral to the meaning of the work, describing a "spiritual warmth or the beginning of an evolution" (Beuys, 1970).

The meaning of the work would completely have changed if this suit had gained moisture-absorbing properties following a treatment with titan oxide nano-particles. The suit would have kept the same rough texture, but its insulation qualities would have disappeared. The opening in the semiotic interpretation of the work would certainly have been disconcerting.

\section{Discussion}

By proposing three fictional scenarios related to the works of Joseph Beuys, we have tried to put into the light the changes produced by the new nano-textiles at different levels, from the way we conceive matter, to the way we deal with it. As these examples show, the sense and the signification of selected works change when the materials used gained new properties and functionalities by means of nano-technologies. In all of the cases, the macro-aesthetic (colour, texture, etc.) qualities do not change significantly. What changes is the epistemological and semiotic categories through which we approach them.

If the materials have a physical existence translated into their physical and chemical properties, there is also a cultural existence of the materials resulting from their millenary usages (Manzini, 1989). There is a "theatre of materials" (Deleuze, 1988, p. 52), as Gilles Deleuze put it, where every material will fold in its own way, reacting to different contexts and forms of interaction. Therefore, the theatre of materials proves to be of relational nature, a place where the semantic automatisms of different materials are negotiated.

The millenary indexation of materials is today destabilised by the multiplication of synthetic materials and the changes occurring in their significance and performance through nano-technological means. There is a phase difference between the physical and cultural orders as well as there is a phase difference between the regimes of macro and nano. However, if we can speak of an identity of textile fibres, with the nano-textiles we should take into consideration the constitution of a nano-scopic identity designed by the "image-objects" of nano-sciences.

Moreover, we should also take into consideration that the two orders, that of the natural world and that of the nano world will exist jointly. We will continue to find traditional fabrics along with new nano-treated fabrics. Most of the time, the aesthetic aspects of these fabrics will not be totally different, but their performances will certainly be different. Not only will we need parallel ecologies (Manzini, 1986), but we will also need to find ways to signalise these differences and make these differences socially and culturally relevant.

The aesthetical concerns related to nano-materials are, as we have showed in this paper, very complex. Not directly perceived by the senses, the nano-objects depend, nevertheless, on the "transmodal logic" (Loeve, 2009) of the practices and instruments necessary for their coming into existence. Several authors have emphasised the aesthetic dimensions (through representation, microscopic manipulation, etc.) implied in the study and the production of nanoobjects (Lorraine Daston, Sacha Loeve, Catherine Allamel-Raffin, David Goodsell). This paradoxical relationship asks for a closer scrutiny of the nature of "intellectual" and "sensory" knowledge (Krzysztof Pomian) and puts into question the theoretical models used until recently in the definition of physical objects.

Still, there is another whole area of aesthetic concern that should be taken into consideration. This area of aesthetic is much more of an operational order and goes beyond the understanding of the aesthetic aspects related to the nature of nano-objects. The aesthetics concerns of nano-treated materials also asks for an evaluation of the way the new nano-treated materials perform into the "human scale 


\section{artnodes}

http://artnodes.uoc.edu

organisation", the way these new materials find their own place into the "theatre of materials".

The researches concerning the means of visualisation and sonification of nano-scopic processes have to reconsider the semiotic nature and the materiality of communication itself. It is where the aesthetic concerns are dealing with the operational aspects of nanomaterials, with their performativity. Not only do we witness a mutation from "representation" to "presentation" (Daston and Galison, 2010), but the transformation of the materials in sensors and actuators transforms them into new communicators.

To face the changes taking place, artists and designers should consider addressing the questions related to nano-technologies not only to understand the nature of the new materials, but also to contribute to the aesthetical and cultural definition of the new nano-materials.

\section{Reference}

ALLAMEL-RAFFIN, C. (2010). "Le texte et l'image dans la formulation de la preuve en physique des materiaux". Revue d'anthropologie des connaissances. No. 3/2010, pp. 476-504.

BENNETT, J. (2008). "Materialismes metalliques". Rue Descartes. No. 59, 1/2008, p. 64.

BENSAUDE-VINCENT B. (2009). "Nanotechnologies: une révolution annoncée". Études, 2009/12 Tome 411, p. 605-616.

BEUYS, J. (1973). "Untitled statement”. In: C. TISDALL, C. (1979). Joseph Beuys. New York: Solomon R. Guggenheim Foundation.

CAUSEY, A. (1998). Oxford History of Art - Sculpture since 1945. Oxford: Oxford Univesity Press.

DASTON, L.; GALISON, P. (2007). Objectivity. New York: Zone Books.

DELEUZE, G. (1988). Le pli. Leibniz et le Baroque. Paris: Les Éditions de Minuit.

DEXLER, E. (1992). "Under special conditions, chemistry can build stable nanostructures". In: K. GERBEL and P. WEIBEL (eds). The World from within - Endo and Nano. Ars Electronica, Linz.

DREXLER, E. (1986). Engines of Creation: The Coming Era of Nanotechnolgogy. Anchor Books: New York.

G00DSELL, D. (2009). "Fact and Fantasy in Nanotech Imagery". Leonardo. Vol. 42, no. 1/2009, pp. 52-57.

HARLAN, V. (1986). Was ist Kunst? Werkstattgespräch mit Beuys, Verlag Urachhaus GmbH: Stuttgart.

KLEIN, E.; BONTEMS, V.; GRINBAUM, A. (2008). "Nanosciences: les enjeux du débat”. Le Débat. 1/2008, n. 148, p. 65-79.

LOEVE, S. (2009). "Le concept de technologie à l'échelle des molécules-machines. Philosophie des techniques à l'usage des citoyens du nanomonde". PhD Thesis. Universite Paris Ouest Nanterre La Defense.
Synthetic Beuys: on Nano-Materials and the Aesthetics of Imperceptibility

LOEVE, S. (2009). "La zone obscure des nanotechnologies”. Appareil, no.2, 2008. [On-line]: <http://revues.mshparisnord.org/appareil/ index.php?id=635. Date of consultation: 2/11/2009>.

MANZINI, E. (1989). Matière de l'invention, Paris: Centre Georges Pompidou, 1989.

NANOGEOPOLITICS ETC. (2005) Group Surveys the Political Landscape [on line]. <www.etcgroup.org/upload/publication/pdf>

SAWHNEY, A.P.S.; CONDON, B.; SINGH, K.V.; PANG, S.S.; LI, G. \& HUI, D. (2008). "Modern Applications of Nanotechnology in Textiles". Textile Research Journal. Vol. 78, no. 8/2008, pp. 731-739.

SIMONDON, G. (1960). "Psychosociologie de la technicite". Bulletin de l'École pratique de psychologie et de pédagogie de Lyon. №. 2, Novembre-Decembre, p. 127-140.

STUARD, C. (2011). "Are nanotextiles making fabric laws wear thin?". The Guardian, 4th of October 2011 [on line]. <http:// www.theguardian.com/nanotechnology-world/nanotextilesfabric-laws-science-nanotechnology $>$.

ZHUKOVSKYI, M.; SANCHEZ-BOTERO, L.M.; McDONALD, MP; HINESTROZA, JP.; KUNO, M. (2014). "Nanowire-functionalized cotton textiles". ACS Applied Materials and Interfaces, vol. 6, no. 4, pp. 2262-2269. <http://dx.doi.org/10.1021/am4052602>

\section{Related links}

Porelle Membranes <http://www.porellemembranes.com > [Accessed: 14th of November 2014]

Kevlar <http://www.dupont.com> [Accessed: 14th of November 2014]

iLoad <http://www.schoeller-textiles.com/technologies/iloadR.html> [Accessed: 14th of November 2014]

"no contact jacket" <http://www.no-contact.com> [Accessed: 14th of November 2014]

National Nanotechnology Initiative (NNI). [On line]: <http://www.nano. gov> [Accessed: 18th of July 2011].

Textiles Nano-technology Laboratory, Cornell University: <http:// nanotextiles.human.cornell.edu $>$ [Accessed: 14th of November 2014].

European Commission <http://ec.europa.eu/research/industrial_ technologies/nanotechnology-fields_en.html> [Accessed: 14th of November 2014].

GOTO-GENESIS AND ONTOLOGY OF TECHNOSCIENTIFIC OBJECTS. Project conducted by Paris 1 University and Technical Uniersity Darmstad: <http://www.goto-objects.eu>. [Accessed: 14th of November 2014].

Tate Gallery <http://www.tate.org.uk/art/artworks/beuys-feltsuit-t07441> 


\section{artnodes}

http://artnodes.uoc.edu

Synthetic Beuys: on Nano-Materials and the Aesthetics of Imperceptibility

\section{Recommended citation}

HEINZEL, Tincuta (2015). "Synthetic Beuys: on Nano-Materials and the Aesthetics of Imperceptibility". In: Pau ALSINA and Ana RODRÍGUEZ GRANELL (coord.). "Art Matters". Artnodes. №. 15, pp. 38-46. UOC [Accessed: dd/mm/yy].

$<$ http://journals.uoc.edu/ojs/index.php/artnodes/article/view/n15-heinzel/n15-heinzel-pdf-en> <http://dx.doi.org/10.7238/a.v0i15.2549>

This article is - unless indicated otherwise - covered by the Creative Commons Spain Attribution 3.0 licence. You may copy, distribute, transmit and adapt the work, provided you attribute it (authorship, journal name, publisher) in the manner specified by the author(s) or licensor(s). The full text of the licence can be consulted here: http://creativecommons.org/licenses/by/3.0/es/deed.en.

\section{CV}

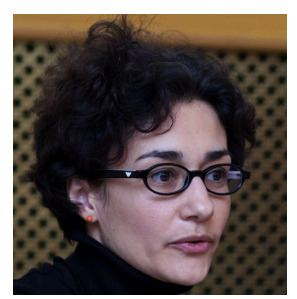

\section{Tincuta Heinzel}

Nottingham Trent University

2580 Association

tinca@textiltronics.com

Tincuta Heinzel is an artist, designer and curator interested in the relationship between arts and technosciences. Following visual arts, design and cultural anthropology studies in Cluj (Romania), she completed her $\mathrm{PhD}$ in aesthetics and arts sciences in 2012 at Paris 1 University (France) with a thesis on the foundations of interactive textiles aesthetics. She initiated, curated and/or coordinated several projects, such as "Artists in Industry" (Bucharest, 2011-2013) and "Haptosonics" (0slo, 2013). As an editor, she published "Art, Space and Memory in the Digital Era" at Paidia Publishing House (Bucharest, 2010) and coordinated Studia Philosophia's issue on the "Phenomenology of Digital Technology" (no. 3/2010). For now, under what she labels as "aesthetics of imperceptibility" she is investigating the aesthetic issues of nano-materiality. Currently she is a research fellow at Nottingham Trent University.

\section{$\bullet$ UOC

